\section{Älterer Vater $=$ mehr Mutationen beim Kind}

\author{
Alte Väter zeugen Kinder mit stärker verändertem Erbgut. Mit jedem \\ zusätzlichen Lebensjahr des Vaters bei der Zeugung steigt die Zahl der \\ veränderten Stellen im Erbgut des Kindes um zwei.
}

\begin{abstract}
sländische Wissenschaftler haben die
DNA von 78 Elternpaaren mit der ihrer Kinder verglichen. Im Fokus standen Denovo-Mutationen. Dabei handelt es sich um genetische Veränderungen, die in den Keimzellen entstehen und sich erst bei den Kindern manifestieren. Mit der Anzahl der De-novo-Mutationen erhöht sich auch das Risiko des Kindes, zum Beispiel an Autismus oder Schizophrenie zu erkranken.

Im Mittel treten bei Kindern im Vergleich zu ihren Eltern etwa 60 De-novoMutationen auf. Jedoch hängt die genaue Zahl stark vom Alter des Vaters zum Zeitpunkt der Zeugung ab: Bereits ein 20-jähriger Vater überträgt im Durchschnitt rund 25 neue Mutationen an sein Kind, ein 40-Jähriger etwa 65. Der starke lineare Effekt von gut zwei zusätzlichen Mutationen pro Jahr ist eindrucksvoll, so die Forscher.
\end{abstract}

\section{Kommentar}

Mütter tragen nur 15 neue Mutationen zum Nachwuchs bei - und das unabhängig von ihrem Alter. Eine Erklärung sehen die Forscher in der unterschiedlichen Art, wie männliche und weibliche Keimzellen entstehen. Bei Mäd- chen entstehen die Eizellen zu Beginn des Lebens und teilen sich anschließend nicht mehr. Ein Mann aber produziert Zeit seines Lebens kontinuierlich neue Spermien. Deren Vorläuferzellen durchlaufen also sehr viel mehr Teilungszyklen und sammeln somit auch mehr
Mutationen an. Interessant sind die Ergebnisse nach Meinung der Wissenschaftler vor allem, weil die Menschen immer später Eltern werden. So waren Männer, die im Jahr 1980 Väter wurden, durchschnittlich 27,9 Jahre alt. 2011 Jahr lag das Durchschnittsalter bei 30 Jahren. Die 1980 geborenen Kinder hatten jeweils rund knapp 60, die 2011 geborenen fast 70 De-novo-Mutationen.

Prof. Kurt Malberg

Kong $\mathrm{A}$ et al. Rate of the de novo mutations and the importance of father's age to disease risk. Nature 2012; 488: 471-5

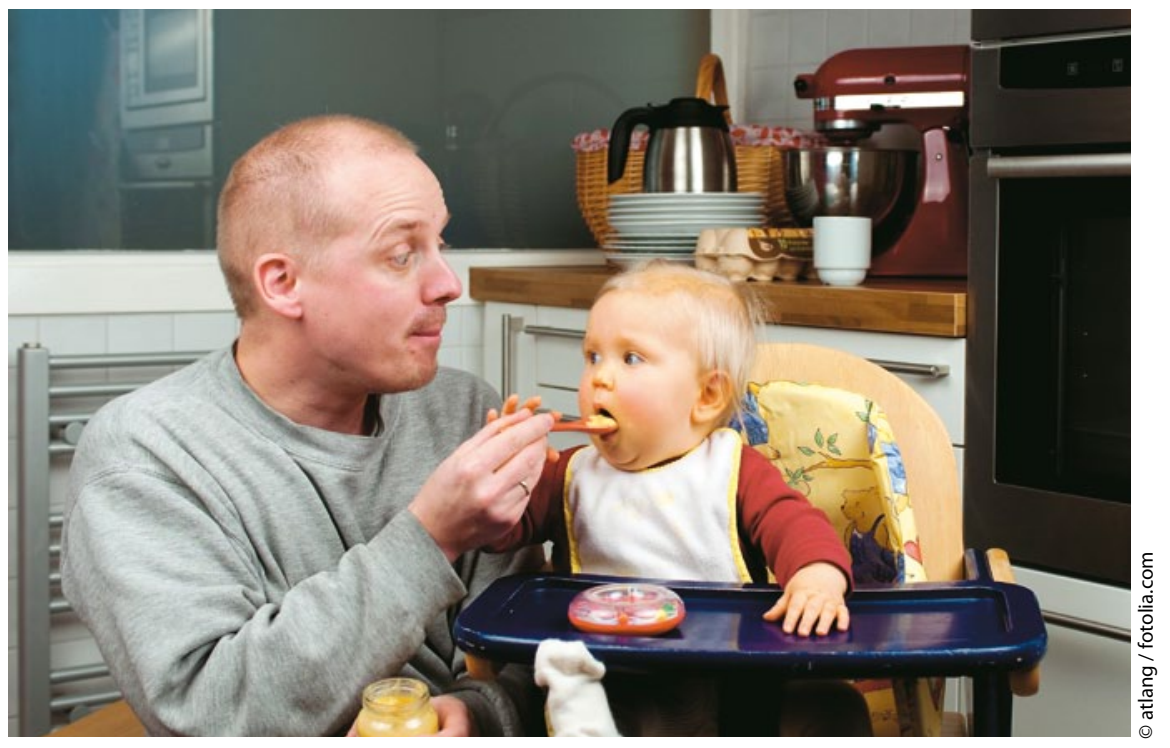

Wie viele Mutationen hat er an seinen Spross übertragen?

\section{Opiatkonsum geht auf den PSA-Spiegel}

In-vitro-Studien zufolge können Opiate die PSA-Sekretion im Prostataepithel unterdrücken. Was in vivo passiert, haben Urologen aus dem Iran untersucht.

F ür eine iranische Studie wurden Männer im Alter zwischen 50 und 70 Jahren rekrutiert, die sich zum Prostatakarzinom-Screening oder wegen Beschwerden des unteren Harntrakts (LUTS) vorstellten. Männer mit Prostatakarzinom, Serum-PSA-Werten $\geq 4 \mathrm{ng} / \mathrm{dl}$, auffälligem Tastbefund, Prostata-Operation oder Medikamenten, die den PSA-Spiegel beeinflussen, waren ausgeschlossen. 56 opiatabhängige Männer, die seit Jahren Opium rauchten oder schluckten (im Median 1,2 g/d), wurden 82 gleich alten Männern ohne Opiatkonsum gegenübergestellt.
Im Vergleich zu den Kontrollpersonen hatten die Opiumkonsumenten signifikant niedrigere Serum-PSA-Spiegel $(0,82$ vs. $1,95 \mathrm{ng} / \mathrm{dl}, \mathrm{p}<0,001)$ und SerumTestosteron-Spiegel (339,1 vs. $396,7 \mathrm{ng} /$ $\mathrm{dl}, \mathrm{p}=0,008)$. Das Absinken der PSAWerte ließ sich jedoch nicht mit einem opiatinduzierten Hypogonadismus erklären. Vielmehr war der Konsum von Opium auch bei eugonadalen Männern mit niedrigeren PSA-Werten assoziiert. Darüber hinaus blieb der Effekt des Opiumkonsums auf das Serum-PSA auch nach Abgleich von Serum-Testosteron und
Prostatavolumen erhalten. Keinen signifikanten Einfluss hatte der Drogengebrauch dagegen auf follikelstimulierendes Hormon (FSH), luteinisierendes Hormon (LH) und Prostatavolumen.

Fazit: Opiatkonsumenten haben niedrigere PSA-Werte, die offenbar unabhängig von einem opiatinduzierten Testosteronmangel auftreten. Eine Anpassung des PSA-Grenzwerts für die Prostatabiopsie erscheint deswegen sinnvoll. Auf welchem Weg Opiate die PSA-Sekretion mindern, ist jedoch noch unklar.

Dr. Beate Schumacher

Hosseini SY et al. Influence of Opioid Consumption on Serum Prostate-specific Antigen Levels in Men Without Clinical Evidence of Prostate Cancer. Urology 2012; 80: 169-73 